REVIEW ARTICLE

Aspirin Intolerance: Experimental Models for Bed-to-Bench

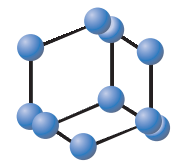

\begin{abstract}
Aspirin is the oldest non-steroidal anti-inflammatory drug (NSAID), and it sometimes causes asthma-like symptoms known as aspirin-exacerbated respiratory disease (AERD), which can be serious. Unwanted effects of aspirin (aspirin intolerance) are also observed in patients with food-dependent exercise-induced anaphylaxis, a type I allergy disease, and aspirin-induced urticaria (AIU). However the target and the mechanism of the aspirin intolerance are still unknown. There is no animal or cellular model of AERD, because its pathophysiological mechanism is still unknown, but it is thought that inhibition of cyclooxygenase by causative agents leads to an increase of free arachidonic acid, which is metabolized into cysteinyl leukotrienes (cysLTs) that provoke airway smooth muscle constriction and asthma symptoms. As the bed-tobench approach, to confirm the clinical discussion in experimental cellular models, we have tried to develop a cellular model of AERD using activated RBL-2H3 cells, a rat mast cell like cell line. Indomethacin (another NSAID and also causes AERD), enhances in vitro cysLTs production by RBL-2H3 cells, while there is no induction of cysLTs production in the absence of inflammatory activation. Since this suggests that all inflammatory cells with activation of prostaglandin and cysLT metabolism should respond to NSAIDs, and then I have concluded that aspirin intolerance should be separated from subsequent bronchoconstriction. Evidence about the cellular mechanisms of NSAIDs may be employed for development of in vitro AERD models as the approach from bench-to-bed.
\end{abstract} Received: June 28, 2016
Revised: September 23, 2016 Accepted: September 29, 2016 DOI:
10.2174/138945011766616100515

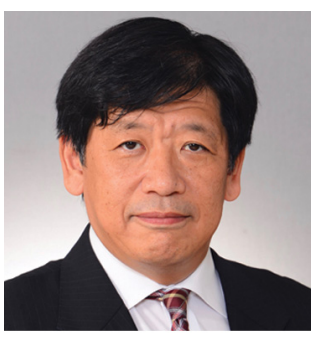

Masamichi Yamashita

Keywords: Arachidonic acid metabolism, aspirin intolerance, aspirin-exacerbated respiratory disease, aspirin-induced urticaria, cysteinyl leukotrienes, food-dependent exercise-induced anaphylaxis, prostaglandins, mast cells.

\section{CLINICAL ASPECTS OF ASPIRIN INTOLERANCE}

\subsection{Aspirin Intolerance and Clinical Aspects of AERD}

Aspirin-exacerbated respiratory disease (AERD) is also known as aspirin-induced asthma or aspirin-intolerant asthma (AIA). It is a respiratory disorder that features nasal obstruction, rhinorrhea, and acute asthma attacks with airway constriction, which is induced by non-steroidal antiinflammatory drugs (NSAIDs) such as aspirin (acetylsalicylic acid; Fig. 1a) [1-3] or indomethacin (Fig. 1b) [4], other medications [5] such as sodium succinate-conjugated corticosteroids (e.g. hydrocortisone sodium succinate; Fig. 1c) food additives such as tartrazine (a yellow food dye; Fig. 1d) or parahydroxybenzoates (antiseptic food additives known as paraben; Fig. 1e), and food components such as sulfites, mint, and salicylate (Fig. 1f) [6,7]. Hypersensitivity to NSAIDs and these causative substances is known as aspirin intolerance.

*Address correspondence to this author at the Laboratory of Food for Health, Department of Bioscience in Daily Life, College of Bioresource Sciences, Nihon University, 1866 Kameino, Fujisawa, Kanagawa 252-0880 Japan; Tel/Fax: +81-466-84-3748; E-mail: may@brs.nihon-u.ac.jp
According to the asthma guideline of the US National Heart, Lung and Blood Institute, $21 \%$ of adult asthma patients and $5 \%$ of pediatric asthma patients have AERD [8], while the Japanese asthma guideline [9] states that $5-10 \%$ of adult asthma patients and 3.6-7.8\% of pediatric asthma patients have AERD. According to both guidelines, the majority of AERD patients are adults.

Females are affected twice as often as males, but other factors such as the family history, ethnicity, or geographic region have no influence [10], suggesting that genetic disorders are not related to the pathogenesis of AERD. Nasal polyps and dysosmia are frequent in AERD patients $[9,11$, 12].

Asthma attacks triggered by aspirin intolerance can be serious, and it was reported that $40 \%$ of patients receiving emergency treatment for asthma have AERD [13, 14]. Since AERD has been reported in patients without known prior exposure to the triggering compound, it seems that the underlying mechanism is not type I allergy [10]. Evidence shows that treatment with chromoglycate is effective for AERD [15], suggesting that mast cells may play a pivotal role in this condition. 
(a)<smiles>CC(=O)Oc1ccccc1C(=O)O</smiles><smiles>COc1ccc2c(c1)c(CC(=O)O)c(C)n2C(=O)c1ccc(Cl)cc1</smiles>

(c)

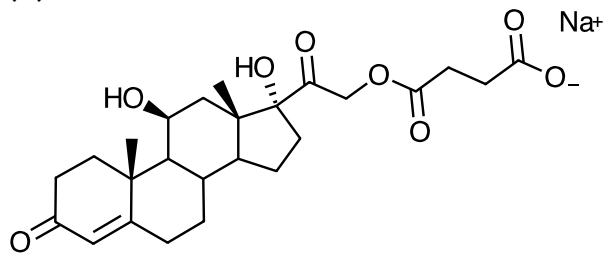

(d)<smiles>CC(O[Na])C1=NN(c2ccc(S(=O)(=O)O[Na])cc2)C(=O)C1C</smiles>

(e)<smiles>O=C(O)c1ccc([OH2+])cc1</smiles>

(f)<smiles>O=C(O)c1ccccc1O</smiles>

Fig. (1). List of causative agents of AERD: (a) acetyl salicylic acid (aspirin), (b) indomethacin, (c) hydrocortisone sodium succinate, (d) tartrazine, (e) parahydroxy-benzoate, and (f) salicylic acid.

\subsection{Aspirin Intolerance in Other Diseases}

Aspirin intolerance is also observed in a condition called aspirin-induced urticaria (AIU), in which urticaria and/or angioedema develops at 1-6 $\mathrm{h}$ after exposure to COX-1inhibiting NSAIDs in $12 \%$ of patients with chronic urticaria [16-18]. AERD and AIU account for the majority of patients with aspirin intolerance.

Harada et al. [19] reported that aspirin intolerance was observed in all of their patients with food-dependent exercise-induced anaphylaxis (FDEIA), a condition combining food allergy and respiratory disorder that is mostly related to wheat or crustaceans. FDEIA differs from AERD, since many patients are teenage boys and $40 \%$ of them have atopic diseases, suggesting that FDEIA is associated with type I allergy. While $10 \%$ of patients develop asthma attacks with exercise several hours after intake of a causative food, they have no symptoms if they do not exercise [20].

These differences between AERD and FDEIA may indicate that the type of allergy (atopic or non-atopic) is not important, or may suggest that non-atopic immune activation underlies the atopic characteristics of FDEIA. Accordingly, it is possible that aspirin intolerance should be separated from the subsequent bronchoconstriction in AERD or FDEIA.

\section{PATHOPHYSIOLOGICAL ASPECTS OF AERD}

\subsection{Arachidonic Acid Metabolism and AERD}

As shown in Fig. (2), the enzyme phospholipase $\mathrm{A}_{2}$ releases fatty acids from cell membrane phospholipids. Arachidonic acid is one of the fatty acids released and it is metabolized into various substances, including prostaglandins (PGs), leukotrienes (LTs), and thromboxanes (TXs), which are thought to make a major contribution to the pathogenesis of inflammatory diseases.

$\mathrm{PGD}_{2}$ and $\mathrm{PGE}_{2}$ are arachidonic acid metabolites produced by cyclooxygenase (COX, also called prostaglandin $\mathrm{G} / \mathrm{H}$ synthase, PGHS, EC 1.14.99.1) which metabolizes ara- chidonic acid to $\mathrm{PGG}_{2}$ by its cyclooxygenase activity and then metabolizes $\mathrm{PGG}_{2}$ to $\mathrm{PGH}_{2}$ by its hydroperoxidase activity (Fig. 2). Metabolites of COX are known to contribute to inflammation. In 1990s, two subtypes of the COX enzyme were found. One of these was named COX-1 and was found to be constitutively expressed by cells. The other was named COX-2 [21, 22], and this was found to be induced by physiological and experimental inflammatory stimuli, such as the carcinogenic promoter 12-O-tetradecanoylphorbol 13acetate, thapsigargin, or calcium ionophore A23187 [2326]. Transcription of COX-2 protein is controlled by various transcription factors, including nuclear factor- $\mathrm{\kappa B}(\mathrm{NF}-\kappa \mathrm{B})$ and AP-1 [27-31], via degradation of the inhibitory protein, I $\mathrm{B}$ [32]. Specific COX-2 inhibitors were developed to avoid the side effect of gastrointestinal ulceration, and it was revealed that selectivity is due to difference of tertiary protein structure between COX-1 and COX-2 [33-36].

Arachidonic acid is also metabolized to leukotriene $\mathrm{A}_{4}$ $\left(\mathrm{LTA}_{4}\right)$ by another pathway involving 5-lipoxygenase (5LOX), after which $\mathrm{LTA}_{4}$ is converted to $\mathrm{LTB}_{4}$ and $\mathrm{LTC}_{4}$. Then $\mathrm{LTC}_{4}$ is metabolized to $\mathrm{LTD}_{4}$, and $\mathrm{LTE}_{4}$ as shown in Fig. (2). $\mathrm{LTC}_{4}, \mathrm{LTD}_{4}$, and $\mathrm{E}_{4}$ contain cysteine residues, and thus are called cysteinyl leukotrienes (cysLTs). Cysteinyl LTs were originally discovered as slow reacting substance of anaphylaxis (SRS-A), which was extracted from the lung tissues of antigen-sensitized guinea pigs, and was shown to constrict airway smooth muscle from these animals more potently, slowly, and continuously than histamine via an antihistamine- resistant mechanism [37].

Urinary concentrations of cysLTs are elevated in AERD patients, even when they have no asthma symptoms [38], and cysLT inhibitors, such as 5-LOX inhibitor [39], or cysLT receptor blockers [40-42] are reported to be safe and effective for AERD, indicating involvement of cysLTs in the mechanism underlying this disease.

\subsection{Target of Aspirin/NSAIDs and Mechanism of AERD}

Aspirin is an anti-inflammatory analgesic agent that has been marketed since 1899 and is the oldest chemically syn- 
thesized drug (Fig. 1a). In the 1970s, it was found that the mechanism of action of aspirin and other acidic NSAIDs involves inhibition of PG production [43-45]. In the 1990s, the molecular mechanism of aspirin was finally revealed to be irreversible acetylation of Ser-530 on COX [46], with inhibition of both COX-1 and COX-2 [23], while most NSAIDs such as indomethacin (Fig. 1b) reversibly inhibit COX.

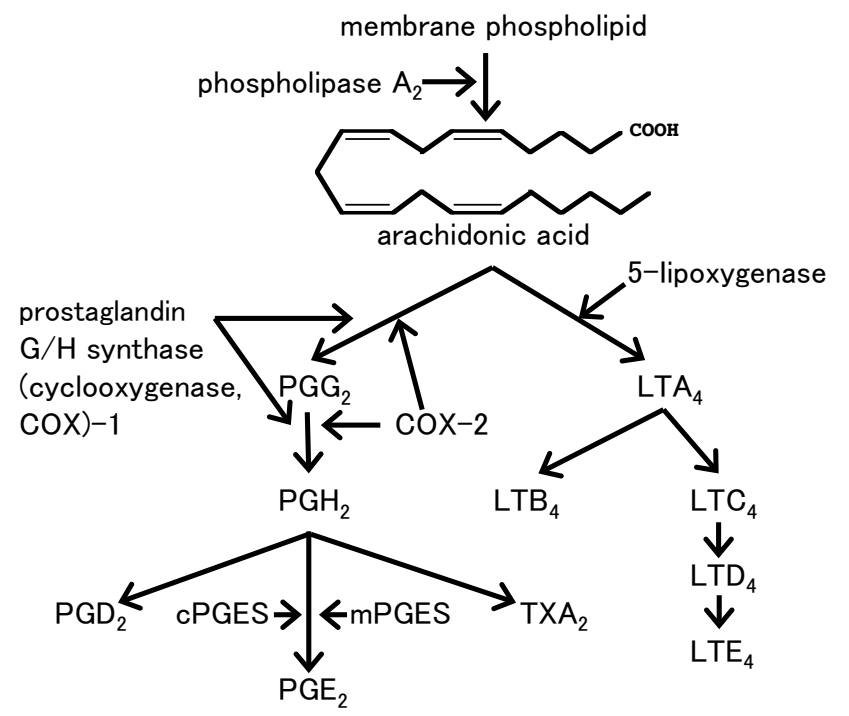

Fig. (2). Metabolic cascade of arachidonic acid.

Almost all (80-100\%) the oral dose of aspirin (100-300 $\mathrm{mg}$ ) is immediately absorbed from the stomach or upper small intestine and the maximum serum concentration is reached within $35 \mathrm{~min}$. Then it is metabolized into salicylic acid (Fig. 3a) and conjugated with a glucuronate or sulfate. A sodium salt of the one of the metabolites, gentisic acid (Fig. 3b), is reported to have an anti-inflammatory effect [47].

Interestingly, selective COX-2 inhibitors have been reported to be safe for AERD patients [48-51], indicating the pivotal involvement of COX-1 in the mechanism of AERD.

In 1990s, it was hypothesized that suppression of prostaglandin production via inhibition of COX leads to accumulation of excess arachidonic acid both inside and outside of cells, after which the excess arachidonic acid is metabolized into cysLTs that cause asthma attacks [38, 52-55].

\section{BED-TO-BENCH APPROACH OF THE EXPERI- MENTAL MODELS WHICH PROPOSING OR CON- FIRMING THE PATHOPHYSIOLOGICAL MECHA- NISMS OF AERD}

The pathogenic mechanism of AERD is still not clear. Most of the research performed has been clinical because useful animal or cellular models do not exist. Some attempts to develop experimental models of AERD are ongoing based on clinical information.

\subsection{Cellular Model of Arachidonic Acid Metabolism Us- ing a Cultured RBL-2H3 Mast Cell Line}

We have tried to develop a cellular model of AERD based on inhibition PG production by NSAIDs, and we pre- viously assessed the effect on cysLT production in the RBL$2 \mathrm{H} 3$ mast cell line derived from rat basophilic leukemia [56]. We choose indomethacin ( $\leqq 3 \mu \mathrm{M}$, Fig. 1b) as the NSAID to avoid unexpected protein acetylation by using aspirin [57]. We found that cysLT production increased when RBL-2H3 cells were pretreated overnight with dinitrophenol (DNP)specific immunoglobulin E (IgE) and then treated with DNPconjugated human serum albumin, creating a cellular model of type I allergy [58-60]. Treatment with indomethacin at concentration up to $3 \mu \mathrm{M}$ did not cause dose-dependent changes of cysLT production, while there was almost $90 \%$ inhibition of $\mathrm{PGD}_{2}$ production. $\mathrm{LTB}_{4}$ production was significantly increased by indomethacin at 1-3 $\mu \mathrm{M}$. Our observation regarding $\mathrm{LTB}_{4}$ is supported by a study of Planaguma et al. [61] using rat Kupffer cells; adding aspirin (up to $5 \mathrm{mM}$ ) doubled $\mathrm{LTB}_{4}$ production while inhibiting $\mathrm{PGE}_{2}$ production approximately $60 \%$.<smiles>CC(=O)Oc1ccccc1C(=O)O</smiles>

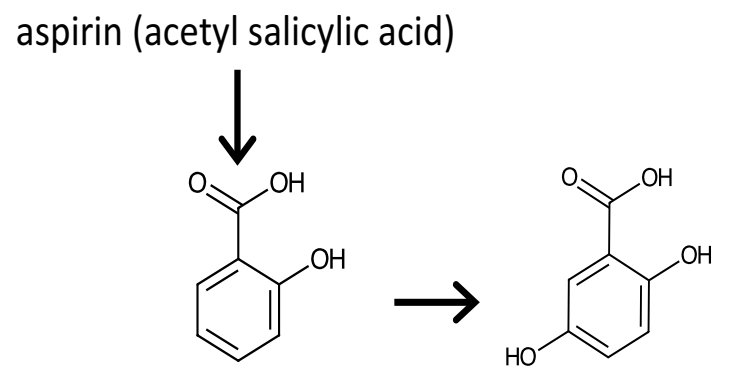

(a) salicylic acid

(b) gentisic acid

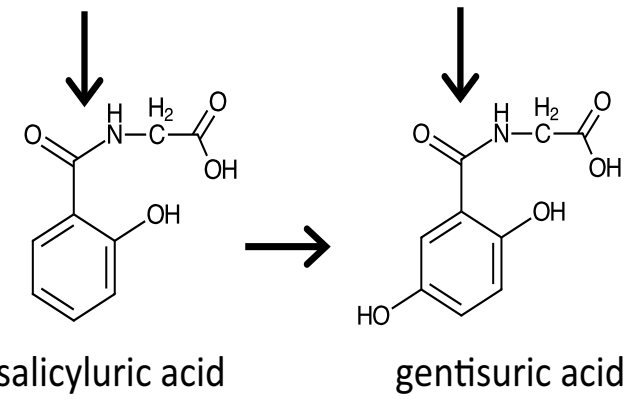

Fig. (3). Aspirin metabolism in humans.

Then we tried adding arachidonic acid $(1-10 \mu \mathrm{M})$ with DNP-HSA to the culture medium of RBL-2H3 cells. Cysteinyl LT production was significantly increased by adding arachidonic acid combined with allergic stimulation, while there was no significant change without allergic stimulation [57].

As mentioned above, AERD is not thought to be a type I allergic disease, so we also tested non-allergic stimulation of RBL-2H3 cells with calcium ionophore A23187 and obtained the similar results.

Our observations indicate that induction of cysLT production by indomethacin may require some inflammatory stimulation of mast cells. If AERD is fundamentally a prob- 
lem with arachidonic acid metabolism, it leads to another question: "Why don't all patients with type I allergy who show activation of mast cells and increased cysLT production have aspirin intolerant?"

\subsection{NSAIDs Increase cysLT Production by Mast Cells}

In our experiments described above [57], we obtained the interesting result that $0.1 \mu \mathrm{M}$ of indomethacin slightly, but significantly increased the production of $\mathrm{LTC}_{4}$, and $\mathrm{LTE}_{4}$. We also tested indomethacin from another source to avoid the influence of contamination by other factors, and the same result was observed.

Togo et al. [62] reported that aspirin and salicylate (both at $100-300 \mu \mathrm{M}$ ) increased $\mathrm{LTC}_{4}$ production by the RBL-2H3 mast cell line and mouse bone marrow-derived mast cells, and suggested that the mechanism involved calcium influx following activation of cytosolic phospholipase $\mathrm{A}_{2}$. We cannot conclude whether their observation corresponds with ours or not, and it is also unclear whether the effect of these NSAIDs is related to AERD.

\subsection{Possible Involvement of Cytokines in PG Production}

Liu et al. [63] studied mice with knockout of microsomal PGE synthase-1 (mPGES-1), which associates with COX-2 and metabolizes $\mathrm{PGH}_{2}$ to $\mathrm{PGE}_{2}$ (Fig. 2). After pretreatment with dust mite extract and challenge with lysine-aspirin (1.2 $\mathrm{mg} / 12 \mu \mathrm{L}$ via a ventilator), there was a marked increase of respiratory tract resistance and elevation of the levels of cysLTs, histamine, and MCP-1 (an indicator of mast cell degranulation) in bronchoalveolar lavage fluid. Ketorolac (a selective COX-1 inhibitor) and celecoxib (a selective COX-2 inhibitor) failed to increase respiratory tract resistance in this model. However, an EP2 receptor agonist significantly inhibited these responses, and EP2 receptor knockout mice showed smaller increases than mPGES-1 knockout mice. They recently observed that interleukin (IL)-33, a type 2 helper $\mathrm{T}$ (Th2) cytokine released from necrotic cells as "alarmin" [64], was highly expressed in the lung epithelium of mPGES-1 knockout mice pretreated with mite extract and in the nasal polyps of AERD patients $[65,66]$. It was reported that IL-33 is produced by mast cells and that it increases the production of IL-4, IL-5, and IL- 6 by bone marrow-derived murine mast cells and a murine mast cell line $(\mathrm{MC} / 9)$ when these cells received $\mathrm{IgE}$ sensitization followed by antigen treatment. It was also reported that the IL-33 receptor (ST-2) is expressed by mast cells after atopic stimulation [67].

Another class of ST-2 positive memory-type Th2 cells, known as pathogenic Th2 cells, was recently proposed to have a role in inflammatory diseases including asthma [68]. Though the relationship between the pathogenic Th2 cells and AERD is unclear, T cells or their cytokines could activate mast cells in AERD patients.

The observation that mPGES knockout mice respond to lysine-aspirin [63] may indicate that inhibition of cytosolic PGES (cPGES) associated with COX-1 (Fig. 4) could be at least partly involved in AERD, suggesting that cPGES activators could be effective for this condition.
Nakatani et al. [69] studied the effect of cPGES knockout, and reported that cPGES-null mice undergo perinatal death with low body weight, hypoplastic skin changes, and alveolar collapse in the lungs at 18.5 days post-coitum. In contrast, heterozygous knockout mice seemed normal, apart from the cPGES protein level. They did not provide information about the effect of NSAIDs on cPGES heterozygous knockout animals.

We previously observed that auranofin, a gold compound for rheumatoid arthritis, induced a COX-1-dependent increase of $\mathrm{PGE}_{2}$ production without significant induction of COX-1 protein within $4 \mathrm{~h}$ after inflammatory treatment of rat peritoneal macrophages, while nitric oxide production was not increased $[25,26,31]$. It was also reported that auranofin induces $\mathrm{p} 23$, a co-chaperone of heat shock protein 90 that was later identified as cPGES (Fig. 2) [70]. If reduction of PG synthesis via cPGES/COX-1 plays an important role in AERD, auranofin or other cPGES activator(s) could be effective for this condition.

Findings in our cellular model suggested that mast cells may require inflammatory activation for overproduction of cysLTs with COX inhibition. Some classes of $\mathrm{T}$ cells and some cytokines may be involved the pathogenesis of AERD by activating mast cells. Therefore, in vitro experiments may be able to identify inflammatory mediators that activate mast cells and PGES activators, with the results having clinical implications.

\subsection{Other Targets of Aspirin, the Bench-to-Bed Ap- proach}

The mechanism through which NSAIDs act on COX is very clear and explains many inflammatory phenomena, but we could not explain all the effects of NSAIDs through inhibition of COX activity.

As described above, some causative substances of AERD may not strongly inhibit COX-1-dependent PG synthesis. We previously observed that the ligands of two well-known nuclear receptors, peroxisome proliferator-activated receptor (PPAR) $\alpha$ and $\gamma$, independently reduced cysLT release from stimulated RBL-2H3 mast cell line [58-60]. This may suggest the possibility of a role of some unknown target(s) of NSAIDs and other causative substances.

Aspirin is reported to be associated with phospholipase $A_{2}$ [71], which is the enzyme that liberates arachidonic acid from membrane phospholipids (Fig. 2).

Aspirin and other NSAIDs are also reported to affect various mitochondrial enzyme complexes, including NADHubiquinone oxidoreductase (complex I), succinate dehydrogenase (complex II), cytochrome bc 1 complex (complex III) and cytochrome c oxidase (complex IV) [72, 73]. Antimycin, a specific complex III inhibitor, is reported to inhibit histamine release from experimentally stimulated human mast cells obtained by bronchoalveolar lavage [74]. Antimycin was also reported to increase reactive oxygen species in the mitochondria of a pollen extract-treated A549 human alveolar epithelial cell line and the authors suggested that damage to mitochondrial respiration-related proteins may exacerbate inflammation [75]. 


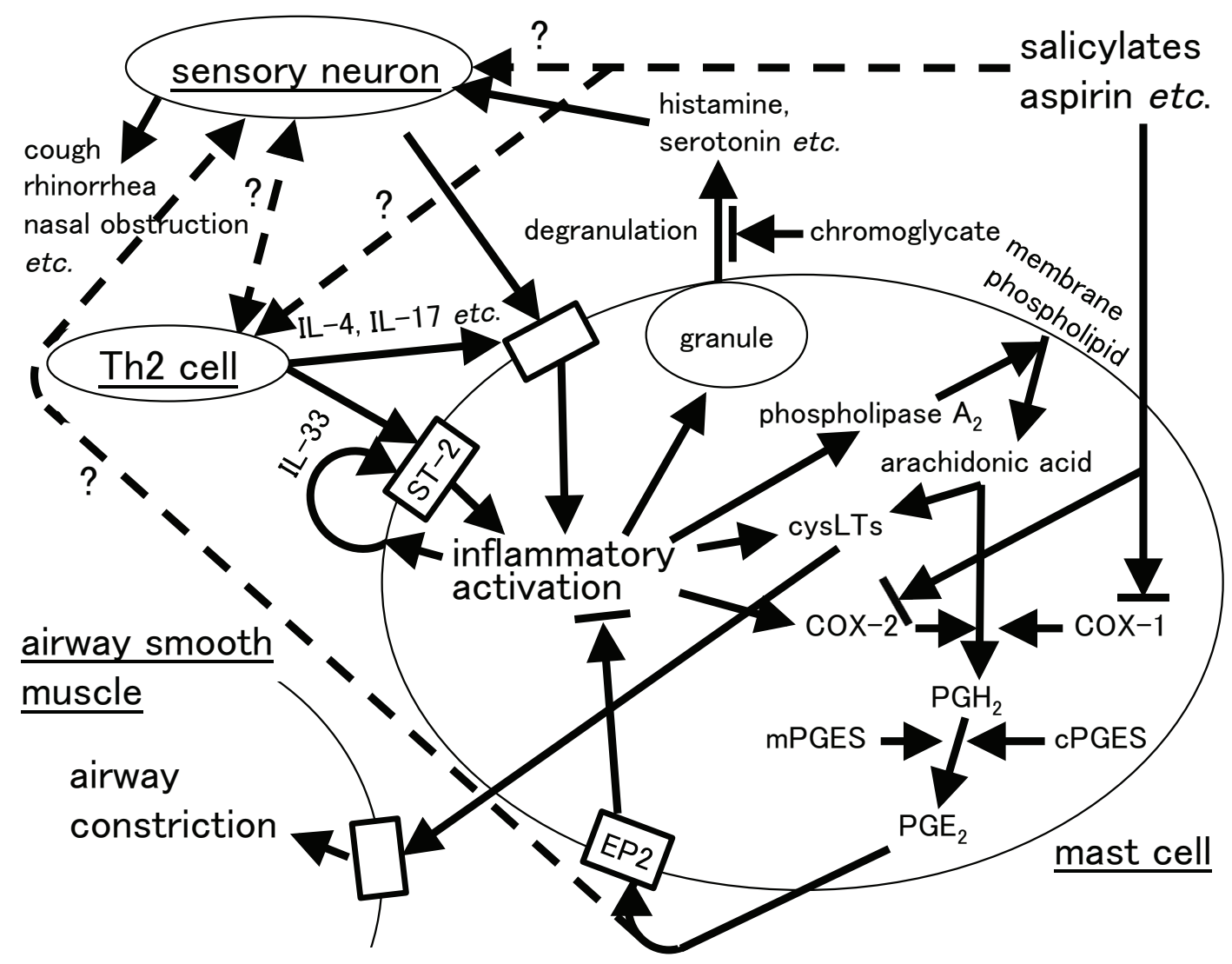

Fig. (4). Diagram of the proposed pathogenesis of AERD. Underlined words indicate tissues or cells. Arrows with a vertical bar $(\rightarrow-1)$ show inhibition, and arrows with a broken line indicate a hypothetical effect.

I found that the amino acid sequence of the acetylated by aspirin in COX (FSLKG from 529 to 533) [46], is also in the primary protein structure [76] of human corona virus HKU1 near the nonstructural protein (nsp) 4 domain which has a similar amino acid alignment to nsp4 of murine hepatitis virus. I could not find a nomenclature for this 5 amino acid site in HKU1, and I cannot predict whether aspirin and other NSAIDs act via this site in humans.

Salicylic acid (Fig. 1f) is secreted by plants in response to pathogens and induces resistance to viruses [77]. The salicylate receptors in plants are nonexpressors of PR gene 1 (NPR1), which is a homolog of IкB in mammals [78], and has NPR1-like proteins 3 , and 4 as paralogues [79, 80]. In tumor necrosis factor-treated COS-1 cells, it has been demonstrated that sodium salicylate (1-20 mM) inhibits the deg-

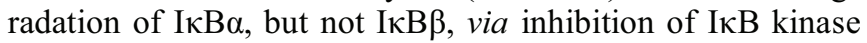
activity [81, 82].

Recently, Honjo et al. reported the discovery of 36 genes related to thermal nociception in Drosophila larvae [83]. Twenty of 36 genes have human orthologs, and some of them are not known to be related to pain sensation. This is interesting because pain sensation in the respiratory tract may be related to cough in asthma patients. $\mathrm{PGE}_{2}$ is known to enhance pain, which is why NSAIDs are analgesics. It is possible that $\mathrm{PGE}_{2}$ or aspirin acts directly or indirectly on these gene products to enhance nociceptive sensation in inflammation.

\section{CONCLUSION}

In traditional Japanese medicine, a disease with a high risk of occurrence in the future, is called "mibyou" [84, 85]. I think that AERD patients who have never experienced an asthma attack could be considered as "mibyou" patients. While asthma attacks associated with AERD are frequently serious, we cannot define whether a person is at risk of AERD or not until asthma occurs following the intake of a causative substance.

If we could determine the mechanism of AERD and identify the risk of asthma during the "mibyou" period, we could prevent AERD and reduce the number of asthma deaths. Further clinical investigations of AERD are needed, and additional basic studies based on the clinical information could also help clinicians to understand the pathophysiological features of this disease.

\section{LIST OF ABBREVIATIONS}

$\begin{array}{lll}\text { 5-LOX } & =5 \text {-lipoxygenase } \\ \text { AERD } & =\text { Aspirin-exacerbated respiratory disease } \\ \text { AIA } & =\begin{array}{l}\text { Aspirin induced asthma, or aspirin- } \\ \text { intolerant asthma }\end{array} \\ \text { AIU } & =\text { Aspirin-induced urticaria } \\ \text { COX } & =\text { Cyclooxygenase }\end{array}$




$\begin{array}{ll}\text { cPGES } & =\text { Cytosolic PGE synthase } \\ \text { cysLT } & =\text { Cysteinyl leukotriene } \\ \text { DNP } & =\text { Dinitrophenol } \\ \text { FDEIA } & =\text { Food-dependent exercise-induced anaphy- } \\ \text { IgE } & =\text { Immunoglobulin E } \\ \text { IL } & =\text { Interleukin } \\ \text { LT } & =\text { Leukotriene } \\ \text { mPGES } & =\text { Microsomal PGE synthase } \\ \text { NF- } \mathrm{B} & =\text { Nuclear factor- } \mathrm{BB} \\ \mathrm{NPR}-1 & =\text { Nonexpressor of PR gene 1 } \\ \text { NSAID } & =\text { Nonsteroidal anti-inflammatory drug } \\ \text { NSP } & =\text { Nonstructural protein } \\ \text { PG } & =\text { Prostaglandin } \\ \text { SRS-A } & =\text { Slow reacting substance of anaphylaxis } \\ \text { Th2 } & =\text { Type 2 helper T } \\ \text { TX } & =\text { Thromboxane }\end{array}$

\section{CONFLICT OF INTEREST}

The author confirm that this article content has no conflict of interest.

\section{ACKNOWLEDGEMENTS}

I wish to thank Dr. Hiroko Watanabe (Kanagawa Prefectural Institute of Public Health) whose lecture on 14 May 2014, proposed the similarity between FDEIA and AERD, and Dr. Kiyoshi Hirahara (Chiba University) whose lecture on 6 October 2015, suggested involvement of IL-33 in nonallergic asthma including AERD.

\section{REFERENCES}

[1] Samter M, Beers RF. Concerning the nature of intolerance to aspirin. J Allergy 1967; 40(5): 281-93.

[2] Widal F, Abrami P, Lermoyez J. First complete description of the aspirin idiosyncrasy-asthma-nasal polyposis syndrome (plus urticaria)-1922 (with a note on aspirin desensitization). By F. Widal, P. Abrami, J. Lermoyez. J Asthma 1987; 24(5): 297-300.

[3] Widal MF, Abrami P, Lermoyez J. Anaphylaxie et idiosyncrasie. La presse médicale 1922; 30: 189-92.

[4] Vanselow NA, Smith JR. Bronchial asthma induced by indomethacin. Ann Intern Med 1967; 66(3): 568-72.

[5] Szczeklik A. Aspirin-induced asthma In: Vane JR, Botting RM, editors. Aspirin and other salicylates 1992. pp. 548-75.

[6] Duthie GG, Wood AD. Natural salicylates: foods, functions and disease prevention. Food Funct 2011; 2(9): 515-20.

[7] Hare LG, Woodside JV, Young IS. Dietary salicylates. J Clin Pathol 2003; 56(9): 649-50.

[8] Expert Panel Report 3: Guidelines for the diagnosis and management of asthma. National Heart Lung and Blood Institute; 2007.

[9] Japanese Society of Allegology. Asthma prevention and management guideline, Japan 2015.

[10] Szczeklik A, Nizankowska E, Duplaga M. Natural history of aspirin-induced asthma. AIANE Investigators. European Network on Aspirin-Induced Asthma. Eur Respir J 2000; 16(3): 432-6.

[11] Berges-Gimeno MP, Simon RA, Stevenson DD. The effect of leukotriene-modifier drugs on aspirin-induced asthma and rhinitis reactions. Clin Exp Allergy 2002; 32(10): 1491-6.
[12] Berges-Gimeno MP, Simon RA, Stevenson DD. The natural history and clinical characteristics of aspirin-exacerbated respiratory disease. Ann Allergy Asthma Immunol 2002; 89(5): 474-8.

[13] Spector SL, Wangaard CH, Farr RS. Aspirin and concomitant idiosyncrasies in adult asthmatic patients. J Allergy Clin Immunol 1979; 64(6 Pt 1): 500-6.

[14] Yoshimine F, Hasegawa T, Suzuki E, et al. Contribution of aspirinintolerant asthma to near fatal asthma based on a questionnaire survey in Niigata Prefecture, Japan. Respirology 2007; 10(4): 477-84.

[15] Imokawa S, Sato A, Taniguchi M, et al. Sodium cromoglycate nebulized solution has an acute bronchodilative effect in patient with aspirin-intolerant asthma (AIA). Jpn J Allergol 1992; 41(10): 1515-20.

[16] Lambrakis P, Rushworth GF, Adamson J, et al. Aspirin hypersensitivity and desensitization protocols: implications for cardiac patients. Ther Adv Drug Saf 2011;2(6): 263-70.

[17] Stevens W, Buchheit K, Cahill KN. Aspirin-exacerbated diseases: Advances in asthma with nasal polyposis, urticaria, angioedema, and anaphylaxis. Curr Allergy Asthma Rep 2015; 15(12): 69.

[18] Sánchez-Borges M, Caballero-Fonseca F, Capriles-Hulett A, et al. Aspirin-exacerbated cutaneous disease (AECD) is a distinct subphenotype of chronic spontaneous urticaria. J Eur Acad Dermatol Venereol 2015; 29(4): 698-701.

[19] Harada S, Horikawa T, Icihashi M. A study of food-dependent exercise-induced anaphylaxis by analyzing the Japanese cases reported in the literature. Jpn J Allergol 2000; 49(11): 1066-73.

[20] Simons FER, Ebisawa M, Sanchez-Borges M, et al. 2015 update of the evidence base: World Allergy Organization anaphylaxis guidelines. World Allergy Organ J 2015; 8(1): 1-16.

[21] O'banion MK, Winn VD, Young DA. cDNA cloning and functional activity of a glucocorticoid-regulated inflammatory cyclooxygenase. Proc Natl Acad Sci USA 1992; 89(11): 4888-92.

[22] Ryseck R, Raynoschek C, Macdonald-Bravo H, et al. Identification of an immediate early gene, $p g h s-B$, whose protein product has prostaglandin synthase/cyclooxygenase activity. Cell Growth Differ 1992; 3(7): 443-50

[23] Yamada M, Niki H, Yamashita M, et al. Prostaglandin $\mathrm{E}_{2}$ production dependent upon cyclooxygenase-1 and cyclooxygenase-2 and its contradictory modulation by auranofin in rat peritoneal macrophages. J Pharmacol Exp Ther 1997; 281(2): 1005-12.

[24] Yamashita M, Ichinowatari G, Yamaki K, et al. Inhibition by auranofin of the production of prostaglandin $\mathrm{E}_{2}$ and nitric oxide in rat peritoneal macrophages. Eur J Pharmacol 1999; 368(2-3): 251-8.

[25] Yamashita M, Niki H, Yamada M, et al. Induction of nitric oxide synthase by lipopolysaccharide and its inhibition by auranofin in RAW 264.7 cells. Eur J Pharmacol 1997; 338(2): 151-8.

[26] Yamashita M, Niki H, Yamada M, et al. Dual effects of auranofin on prostaglandin $\mathrm{E}_{2}$ production by rat peritoneal macrophages. Eur J Pharmacol 1997; 325(2-3): 221-7.

[27] Adcock I, Newton R, Barnes P. NF- $\mathrm{KB}$ involvement in IL-1 $\beta$ induction of GM-CSF and COX-2: inhibition by glucocorticoids does not require I-KB. Biochem Soc Trans 1997; 25(2): 154S-S.

[28] Crofford LJ, Tan B, Mccarthy CJ, et al. Involvement of nuclear factor $\mathrm{\kappa B}$ in the regulation of cyclooxygenase-2 expression by interleukin-1 in rheumatoid synoviocytes. Arthritis Rheum 1997; 40(2): 226-36.

[29] Sen R, Baltimore D. Inducibility of $\kappa$ immunoglobulin enhancerbinding protein NF- $\mathrm{\kappa B}$ by a posttranslational mechanism. Cell 1986; 47(6): 921-8.

[30] Yamashita M, Ashino S, Oshima Y, et al. Inhibition of TPAinduced NF- $\mathrm{KB}$ nuclear translocation and production of $\mathrm{NO}$ and $\mathrm{PGE}_{2}$ by the anti-rheumatic gold compounds. J Pharm Pharmacol 2003; 55(2): 245-51.

[31] Yamashita M, Ohuchi K, Takayanagi M. Effects of chrisotherapeutic gold compounds on prostaglandin $E_{2}$ production. Curr Drug Targets-Inflamm Allergy 2003; 2(3): 216-23.

[32] Neuveut C, Suzan M, Querat G, et al. HIV1 infection of human monocytes and macrophages promotes induction or translocation of NF-KB-related factors. Res Virol 1991; 142(2-3): 227-31.

[33] Masferrer JL, Zweifel BS, Manning PT, et al. Selective inhibition of inducible cyclooxygenase 2 in vivo is antiinflammatory and nonulcerogenic. Proc Natl Acad Sci USA 1994; 91(8): 3228-32.

[34] Futaki N, Yoshikawa K, Hamasaka Y, et al. NS-398, a novel nonsteroidal anti-inflammatory drug with potent analgesic and antipyretic effects, which causes minimal stomach lesions. Gen Pharmacol 1993; 24(1): 105-10. 
[35] Kurumbail RG, Stevens AM, Gierse JK, et al. Structural basis for selective inhibition of cyclooxygenase-2 by anti-inflammatory agents. Nature 1996; 384(6610): 644-8.

[36] Luong C, Miller A, Barnett J, et al. Flexibility of the NSAID binding site in the structure of human cyclooxygenase-2. Nat Struct Biol 1996; 3(11): 927-33.

[37] Brocklehurst WE. The release of histamine and formation of a slow-reacting substance (SRS-A) during anaphylactic shock. J Physiol 1960; 151(3): 416-35.

[38] Christie PE, Tagari P, Ford-Hutchinson AW, et al. Urinary leukotriene $\mathrm{E}_{4}$ after lysine-aspirin inhalation in asthmatic subjects. Am Rev Respir Dis 1992; 146(6): 1531-4.

[39] Fischer AR, Rosenberg MA, Lilly CM, et al. Direct evidence for a role of the mast cell in the nasal response to aspirin in aspirinsensitive asthma. J Allergy Clin Immunol 1994; 94(6): 1046-56.

[40] Dahlén S-E, Malmström K, Nizankowska EWA, et al. Improvement of aspirin-intolerant asthma by montelukast, a leukotriene antagonist. Am J Respir Crit Care Med 2002; 165(1): 9-14.

[41] Stevenson DD, Simon RA, Mathison DA, et al. Montelukast is only partially effective in inhibiting aspirin responses in aspirinsensitive asthmatics. Ann Allergy Asthma Immunol. 2000; 85(6 Pt 1): 477-82.

[42] Yamamoto H, Nagata M, Kuramitsu K, et al. Inhibition of analgesic-induced asthma by leukotriene receptor antagonist ONO-1078. Am J Respir Crit Care Med 1994; 150(1): 254-7.

[43] Ferreira SH, Moncada S, Vane JR. Indomethacin and aspirin abolish prostaglandin release from the spleen. Nat New Biol 1971; 231(25): 237-9.

[44] Smith JB, Willis AL. Aspirin selectively inhibits prostaglandin production in human platelets. Nat New Biol 1971; 231: 235-7.

[45] Vane JR. Inhibition of prostaglandin synthesis as a mechanism of action for aspirin-like drugs. Nat New Biol 1971; 231: 232-5.

[46] Shimokawa T, Smith WL. Prostaglandin endoperoxide synthase. The aspirin acetylation region. J Biol Chem 1992; 267(17): 1238792.

[47] Smith MJH. The estimation of sodium genistate in tablets and injections. J Pharm Pharmacol 1950; 2(1): 439-43.

[48] Kowalski ML, Makowska JS, Blanca M, et al. Hypersensitivity to nonsteroidal anti-inflammatory drugs (NSAIDs) - classification, diagnosis and management: review of the EAACI/ENDA and GA2LEN/HANNA. Allergy 2011; 66(7): 818-29.

[49] Morales DR, Lipworth BJ, Guthrie B, et al. Safety risks for patients with aspirin-exacerbated respiratory disease after acute exposure to selective nonsteroidal anti-inflammatory drugs and COX-2 inhibitors: Meta-analysis of controlled clinical trials. J Allergy Clin Immunol 2014; 134(1): 40-5.e10.

[50] Szczeklik A, Nizankowska E, Bochenek G, et al. Safety of a specific COX-2 inhibitor in aspirin-induced asthma. Clin Exp Allergy 2001; 31(2): 219-25.

[51] Szczeklik A, Sanak M. The role of COX-1 and COX-2 in asthma pathogenesis and its significance in the use of selective inhibitors. Clin Exp Allergy 2002; 32(3): 339-42.

[52] Knapp HR, Sladek K, Fitzgerald GA. Increased excretion of leukotriene $\mathrm{E}_{4}$ during aspirin-induced asthma. J Lab Clin Med 1992; 119(1): 48-51.

[53] Kumlin M, Dahlen B, Bjorck T, et al. Urinary excretion of leukotriene $\mathrm{E}_{4}$ and 11-dehydro-thromboxane $\mathrm{B}_{2}$ in response to bronchial provocations with allergen, aspirin, leukotriene $\mathrm{D}_{4}$, and histamine in asthmatics. Am Rev Respir Dis 1992; 146(1): 96-103.

[54] Sladek K, Dworski R, Soja J, et al. Eicosanoids in bronchoalveolar lavage fluid of aspirin-intolerant patients with asthma after aspirin challenge. Am J Respir Crit Care Med 1994; 149(4): 940-6.

[55] Sladek K, Szczeklik A. Cysteinyl leukotrienes overproduction and mast cell activation in aspirin-provoked bronchospasm in asthma. Eur Respir J 1993; 6(3): 391-9.

[56] Morita Y, Siraganian RP. Inhibition of IgE-mediated histamine release from rat basophilic leukemia cells and rat mast cells by inhibitors of transmethylation. J Immunol 1981; 127(4): 1339-44.

[57] Ashino S, Yamashita M, Okuyama K, et al. Effects of the inhibition of prostaglandin production on leukotriene production in rat mast cell line RBL-2H3. J Tohoku Pharmac Univ 2003; 49: 131-6.

[58] Yamashita M. Peroxisome proliferator-activated receptor $\alpha$ independent effects of peroxisome proliferators on cysteinyl leukotriene production in mast cells. Eur J Pharmacol 2007; 556(1-3): 172-80.
[59] Yamashita M. PPAR $\alpha / \gamma$-independent effects of PPAR $\alpha / \gamma$ ligands on cysteinyl leukotriene production in mast cells. PPAR Res 2008; 2008 Article ID 293538: 1-6.

[60] Yamashita M, Kushihara M, Hirasawa N, et al. Inhibition by troglitazone of the antigen-induced production of leukotrienes in immunoglobulin E-sensitized RBL-2H3 cells. Br J Pharmacol 2000; 129(2): 367-73.

[61] Planaguma A, Titos E, Lopez-Parra M, et al. Aspirin (ASA) regulates 5-lipoxygenase activity and peroxisome proliferator-activated receptor alpha-mediated CINC-1 release in rat liver cells: novel actions of lipoxin $\mathrm{A}_{4}\left(\mathrm{LXA}_{4}\right)$ and ASA-triggered 15-epi-LXA 4 . FASEB J 2002; 16(14): 1937-9.

[62] Togo K, Suzuki Y, Yoshimaru T, et al. Aspirin and salicylates modulate IgE-mediated leukotriene secretion in mast cells through a dihydropyridine receptor-mediated $\mathrm{Ca}^{2+}$ influx. Clin Immunol 2009; 131(1): 145-56.

[63] Liu T, Laidlaw TM, Katz HR, et al. Prostaglandin $\mathrm{E}_{2}$ deficiency causes a phenotype of aspirin sensitivity that depends on platelets and cysteinyl leukotrienes. Proc Natl Acad Sci USA 2013; 110(42): 16987-92.

[64] Miller AM. Role of IL-33 in inflammation and disease. J Inflamm (Lond) 2011; 8: 22-.

[65] Laidlaw TM, Boyce JA. Aspirin-exacerbated respiratory disease new prime suspects. N Engl J Med 2016; 374(5): 484-8.

[66] Liu T, Kanaoka Y, Barrett NA, et al. Aspirin-exacerbated respiratory disease involves a cysteinyl leukotriene-driven IL-33mediated mast cell activation pathway. J Immunol 2015; 195(8): 3537-45.

[67] Hsu C-L, Neilsen CV, Bryce PJ. IL-33 is produced by mast cells and regulates IgE-dependent inflammation. PLoS ONE 2010; 5(8): e11944.

[68] Hirahara K, Nakayama $\mathrm{T}$. $\mathrm{CD}^{+} \mathrm{T}$ cell subsets in inflammatory diseases: beyond the Th1/Th2 paradigm. Int Immunol 2016; 28(4): 163-71.

[69] Nakatani Y, Hokonohara Y, Kakuta S, et al. Knockout mice lacking cPGES/p23, a constitutively expressed $\mathrm{PGE}_{2}$ synthetic enzyme, are peri-natally lethal. Biochem Biophys Res Commun 2007; 362(2): 387-92.

[70] Tanioka T, Nakatani Y, Semmyo N, et al. Molecular identification of cytosolic prostaglandin $\mathrm{E}_{2}$ synthase that is functionally coupled with cyclooxygenase- 1 in immediate prostaglandin $\mathrm{E}_{2}$ biosynthesis. J Biol Chem 2000; 275(42): 32775-82.

[71] Singh RK, Ethayathulla AS, Jabeen T, et al. Aspirin induces its anti-inflammatory effects through its specific binding to phospholipase $\mathrm{A}_{2}$ : Crystal structure of the complex formed between phospholipase $\mathrm{A}_{2}$ and aspirin at $1.9 \AA$ resolution. J Drug Target 2005; 13(2): 113-9.

[72] Raza H, John A, Benedict S. Acetylsalicylic acid-induced oxidative stress, cell cycle arrest, apoptosis and mitochondrial dysfunction in human hepatoma HepG2 cells. Eur J Pharmacol 2011; 668(1-2): $15-24$.

[73] Sandoval-Acuña C, Lopez-Alarcón C, Aliaga ME, et al. Inhibition of mitochondrial complex I by various non-steroidal antiinflammatory drugs and its protection by quercetin via a coenzyme Q-like action. Chem Biol Interact 2012; 199(1): 18-28.

[74] Cross LJM, Heaney LG, Ennis M. Further characterisation of substance $\mathrm{P}$ induced histamine release from human bronchoalveolar lavage mast cells. Inflamm Res 1996; 45 (Suppl 1): S11-2.

[75] Aguilera-Aguirre L, Bacsi A, Saavedra-Molina A, et al. Mitochondrial dysfunction increases allergic airway inflammation. J Immunol 2009; 183(8): 5379-87.

[76] Woo PCY, Lau SKP, Yip CCY, et al. Comparative Analysis of 22 Coronavirus HKU1 Genomes Reveals a Novel Genotype and Evidence of Natural Recombination in Coronavirus HKU1. J Virol 2006; 80(14): 7136-45.

[77] White RF. Acetylsalicylic acid (aspirin) induces resistance to tobacco mosaic virus in tobacco. Virology 1979; 99(2): 410-2.

[78] Durrant WE, Dong X. Systemic acquired resistance. Annu Rev Phytopathol 2004; 42(1): 185-209.

[79] Fu ZQ, Dong X. Systemic acquired resistance: turning local infection into global defense. Annu Rev Plant Biol 2013; 64(1): 839-63. 
[80] Fu ZQ, Yan S, Saleh A, et al. NPR3 and NPR4 are receptors for the immune signal salicylic acid in plants. Nature 2012; 486(7402): 228-32.

[81] Alpert D, Vilček J. Inhibition of IкB kinase activity by sodium salicylate in vitro does not reflect its inhibitory mechanism in intact cells. J Biol Chem 2000; 275(15): 10925-9.

[82] Yin M-J, Yamamoto Y, Gaynor RB. The anti-inflammatory agents aspirin and salicylate inhibit the activity of IкB kinase- $\beta$. Nature 1998; 396(6706): 77-80
[83] Honjo K, Mauthner SE, Wang Y, et al. Nociceptor-enriched genes required for normal thermal nociception. Cell Rep 2016; 16(2): 295-303.

[84] Tsushima M. Mibyo (preventive medicine) in aged society. Nihon Ronen Igakkai Zasshi 2002; 39(3): 237-45.

[85] Tsushima M. The concept of Mibyou and the need of its treatment for the coming advanced aged society-in order to prevention for nursing and care. Nihon Ronen Igakkai Zasshi 2006; 43(1): 74-7.

PMID: 27719658 